Article

\title{
Sustainability Assessment of the Green Compost Production Chain from Agricultural Waste: A Case Study in Southern Italy
}

\author{
Maria Pergola ${ }^{1}$, Alessandro Persiani ${ }^{1}$, Vittoria Pastore ${ }^{1}$, Assunta Maria Palese ${ }^{1, *}$, \\ Carmine D'Adamo ${ }^{1}$, Enrica De Falco ${ }^{2}$ and Giuseppe Celano ${ }^{2}$ (D) \\ 1 Ages s.r.l.s Spin-off Accademico, Università degli Studi della Basilicata, Viale dell'Ateneo Lucano 10, \\ 85100 Potenza, PZ, Italy; mariateresa_pergola@virgilio.it (M.P.); persianialessandro@gmail.com (A.P.); \\ ingvittoriapastore@gmail.com (V.P.); carminedadamo@hotmail.it (C.D.) \\ 2 Dipartimento di Farmacia (DIFARMA), Università degli Studi di Salerno, Via Giovanni Paolo II, 132, \\ 84084 Fisciano, SA, Italy; edefalco@unisa.it (E.D.F.); gcelano@unisa.it (G.C.) \\ * Correspondence: palesedina@gmail.com; Tel.: +39-347-005-5234
}

Received: 22 December 2019; Accepted: 1 February 2020; Published: 4 February 2020

\begin{abstract}
Horticultural farms are faced with the problem of disposing of huge amounts of agricultural by-products whose management requires sustainable solutions. Composting means to recycle organic waste to make compost - a high agronomic value product-able to positively affect soil quality: A good occasion to switch definitively from a conventional agriculture to an organic one. Nevertheless, composting can have negative direct/indirect environmental impacts. The aim of this research was to assess the sustainability of a windrow composting system, able to treat agricultural green waste of different typology ("light" and "heavy" with dry matter below or above 10\%, respectively). Environmental impacts, energy consumptions, and production costs of all composting stages were evaluated by Life Cycle Assessment. Results show that the production of 1 ton of compost caused $\mathrm{CO}_{2}$ eq emissions ranging from 199 to $250 \mathrm{~kg}$ and required between 1500 and $2000 \mathrm{MJ}$ of energy; costs ranged between 98 and 162 euro, nevertheless lesser than the commercial green compost. The raw material typology affected significantly the composting process making compost based on "heavy" materials the most sustainable. These findings underline the need to spread this low technology process, easy to apply, especially in organic farms, and to promote the agronomic use of compost.
\end{abstract}

Keywords: green waste management; composting on farm; life cycle assessment; energy analysis; life cycle costing

\section{Introduction}

For several years horticultural farms have faced the problem of disposing of vegetable biomasses resulting from residues of agricultural crops and trees. The growing attention of institutions and of the public to environmental issues and the application of the existing legislation [1] have determined the need to apply sustainable solutions to the management of these agricultural by-products. The supply of livestock feed [2] is the most common recovery form of these residues. In most cases, this waste, as it is, is delivered at the livestock farms, with contract of assignment, and it is mostly used fresh, as much of it is waste from the processing of vegetables intended for fresh consumption. This type of recovery, however, is not always possible. For instance, tomato peels, corn waste, and other lignocellulosic materials have physical and chemical characteristics such that it is possible to proceed only to their ensiling. Moreover, when the quality of the waste is not suitable for animal feed (i.e., for the presence of soil particles dirtying crop residues), waste is intended at the agronomic use on the land. At the same time, this practice is quite easy for residues produced in the field but not for 
those produced in warehouses and processing units of agricultural products. In fact, for the latter there are additional important costs (i.e., loading, transportation, and unloading) and the practice is not achievable when soils are wet. In addition, the continuous vegetable residues supply to the soil could cause the accumulation of pathogens in the field and environmental pollution due to nitrates leaching phenomena.

Green residues, together with waste of agribusiness, can also be used to produce biogas. In this way, farms can produce energy from renewable sources; improve their economy; release lower greenhouse gases; enhance the quality of the fertilizer production; implement the recycling of their waste; cause less pollution from smells; and improve the sanitation conditions of the company [3]. At the same time, biogas plants have some disadvantages: Agricultural residues should be used in places not far from the biogas plant, since their transport and storage require additional costs and the disposal of the liquid digestate on fields is problematic.

Of great environmental interest are also the experimentations to produce biopolymers from waste materials, such as those derived from food industry (canning, casearia, and tomato processing) but also from algae, corn stubbles, or from the differentiated collection of the organic fraction from municipal waste. Using local agricultural products, the biopolymers can reduce the dependence on imported fossil fuels and increase the demand for products generated by European agriculture, supporting the development of rural areas. The biopolymers also help to create end-of-life options for efficient and sustainable bioplastic waste, because they can be disposed of in several ways as composting [4].

The most reliable and common practice to the management of agricultural by-products is composting: The only technique that allows the recycling of "green waste", so that the problem becomes an important factor of production. Composting is a waste management system that creates a recycled product, which is carbon (C) rich and free of most pathogens and weed seeds [5]. According to Brown et al. [6], composting can be considered a C-based system, similar to reforestation, agricultural management practices, or other waste management industries and it is one of the most frequently alternatives to landfill [7]. Composting decreases environmental problems related to waste management by reducing waste volumes and by killing potentially dangerous organisms. The agricultural utilization of compost could meet the target objective of European Union countries to decrease the quantity of organic waste going to landfill sites by $20 \%$ by 2010 and by $50 \%$ by 2050 [8].

According to Saer et al. [9], several studies have shown the environmental benefits of compost use for improving soil quality, such as:

$\checkmark \quad$ Incorporating organic matter [10-12], nutrients and electrolytes into the soil [13];

$\checkmark \quad$ reducing the need for fertilizers [14], pesticides and peat use [15], activating a wide ranges of natural disease suppressiveness mechanisms against plants pathogens and bio stimulation able to improve the overall plant status [16];

$\checkmark \quad$ improving soil structure, density and porosity [17-25], which increase water retention capacity and reduce erosion and nutrient leaching [20,26]; and

$\checkmark \quad$ enhancing carbon storage capacity in the soil, thus, reducing global warming $[24,27,28]$.

Therefore, increasing attention is devoted to soil management practices aimed to improve both soil organic carbon incorporation and soil organic matter (SOM) accumulation, as the addition of organic materials and, even more, the use of compost obtained by facilities located in agricultural companies. It is therefore possible to switch from a conventional agriculture to an organic one. Despite these environmental benefits, composting could have negative direct and indirect environmental impacts. Referring to direct negative impacts, on one hand, there are $\mathrm{CO}_{2}$ emissions from decomposing organic matter in compost piles and that usually are not considered as additional GHG emissions since they are biogenic and part of the short-term $\mathrm{C}$ cycle [6]; and on the other hand, there are methane $\left(\mathrm{CH}_{4}\right)$, nitrous oxide $\left(\mathrm{N}_{2} \mathrm{O}\right)$, and ammonia $\left(\mathrm{NH}_{3}\right)$ emissions from methanogenic and denitrification processes occurring during the composting process under anaerobic conditions, which result in odor and additional GHG emissions [29-31]. 
Many researches have analyzed indirect emissions by means of life cycle assessment (LCA). As reported in Pergola et al. [32], some have taken into account the manure processing technologies along the entire life cycle of manure and its end products [33,34]; others, industrial composting and waste management systems [35-40]; still others, bio waste treatments [41] and food waste home composting system [9]. On the contrary, there are no references in literature on the environmental impacts occurring during the on-farm composting of green waste.

In the agricultural sector, another recent topical subject is the energy use. Pergola et al. [32] have assessed the energy sustainability of one ton of compost from dairy cattle/buffalo manure in two on-farm facilities operating with different bulking agents. Cumulative energy demand has been evaluated by Martínez-Blanco et al. [42] for home and industrial composting of the source-separated organic fraction of municipal solid waste, and by Colón et al. [43] for an experimental home composting process of leftovers of raw fruits and vegetables. However, a comprehensive assessment of the compost chain sustainability should also consider an economic perspective. Therefore, the combination of an economic, environmental and energy analysis of a production system may be more useful to find and apply the best management strategies [32,44-47].

The present study is part of the CarbOnFarm project Life+ ENV/IT/000719. The project is focused on the implementation of both demonstrative and innovative strategies based, respectively, on the restoration of SOM function in agricultural soil with local agricultural valorization of recycled waste biomasses, and the soil application of green chemistry products. The project intends to address the target environmental problems related to the decrease of soil organic carbon content and of soil degradation processes of the agricultural areas of Mediterranean countries, which represents a chiefly target objective advised by EU Soil Thematic Strategy. One of the specific objectives of the project is to promote the economic and productive enhancement of residual biomass from agriculture in order to obtain a high-quality compost made with the adoption of on farm facilities. Therefore, the specific aim of the present research was to determine environmental impacts, energy consumptions, and production costs of a windrow composting system using LCA approach to evaluate all the stages of the agricultural green waste composting process, including bulking agent acquisition and transport; agricultural waste transport; and compost production, transport, and distribution on field.

\section{Description of the Composting Plant}

Composting plant is located in Salerno province (Campania region, Italy), precisely in Eboli $\left(40^{\circ} 33^{\prime} 11.48^{\prime \prime} \mathrm{N}, 14^{\circ} 57^{\prime} 43.87^{\prime \prime} \mathrm{E}\right)$, and it is managed by a private agricultural farm (Prima Luce) with the aim to develop a prototype of a composting facility based on confined windrows for the production of compost on farm.

This composting plant (Figure 1) covers a surface area of $4180 \mathrm{~m}^{2}$ (Figure 2) and is composed as follows: A proofed concrete bed of $2160 \mathrm{~m}^{2}$, inclusive of channels and drainage well for liquid residues; covering structures for this $2160 \mathrm{~m}^{2}$ area; automatic blowing system ( 5 blowers) for aeration with air pipes; automatic system for the recovery of processing waters (submersible pump); electric control panel inclusive of monitoring probe-systems (temperature, oxygen, humidity, data logger).

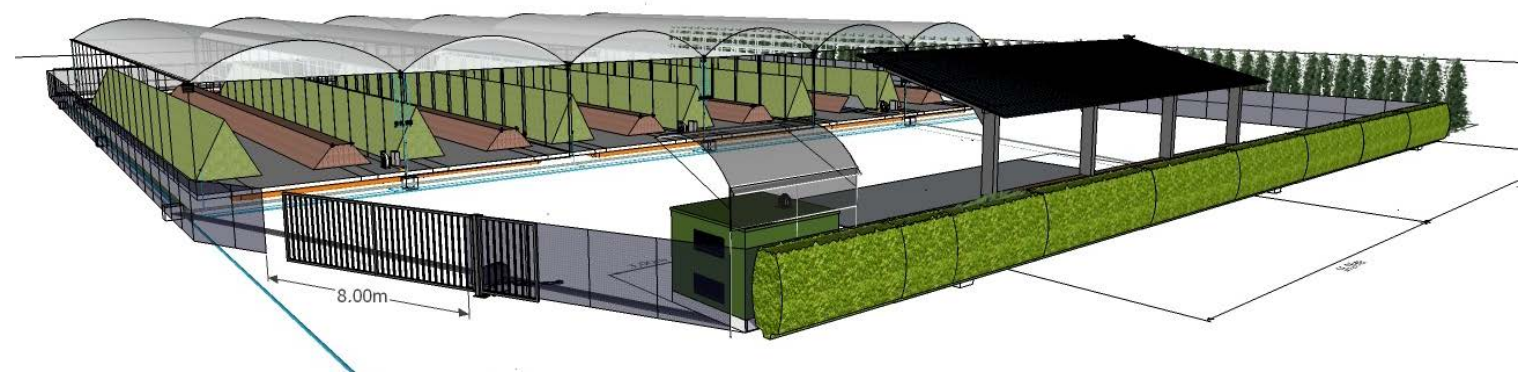

Figure 1. Composting plant in $3 \mathrm{D}$ vision. 


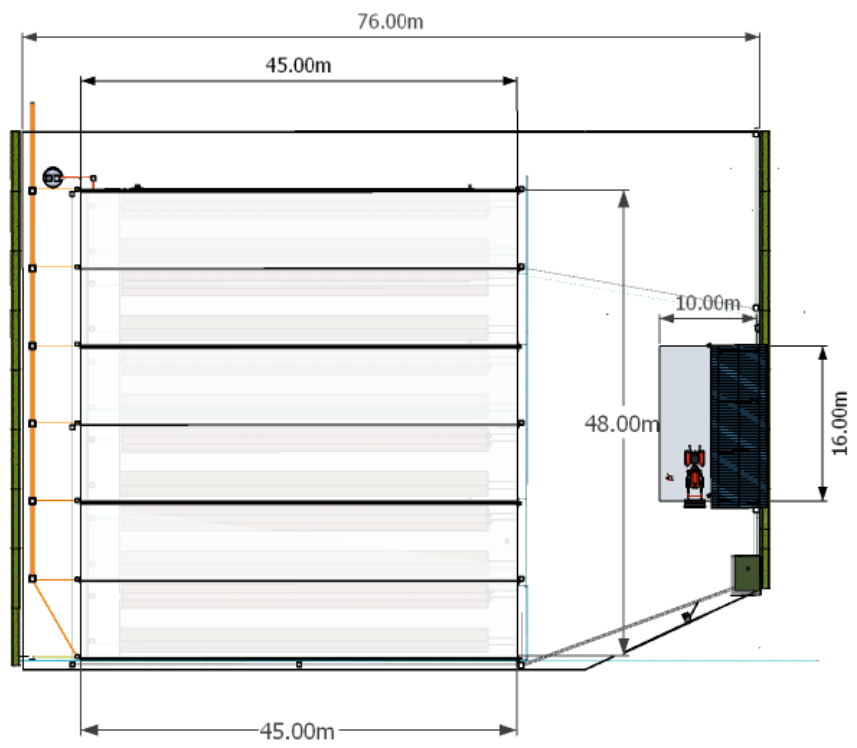

Figure 2. Composting facility in plan.

The composting process combines an aerated static pile technique with weekly turning windrow cycles. During the first three weeks of the bio-oxidation phase, the fan of the aeration system pushes air almost continuously through the composting mass. In this phase, internal temperature windrow reaches $60^{\circ} \mathrm{C}$ at least per 3 days. From the fourth to the seventh week, the blower pushes air according to the following cycle: 5 minutes on, 55 minutes off. During all this period air insufflation is combined with weekly windrow turning. From the eighth week until the end of the process in windrow (60 days, $35-45^{\circ} \mathrm{C}$ ), the compost is only turned. During the following thirty days the compost is arranged in pile to complete the curing phase controlled by temperature. In the second phase of the composting procedure (around 50 days), the turned windrow composting method is used. The compost mix is aerated by a windrow turner which is powered by a farm tractor (PTO). This combined composting procedure represents a low technology and medium labor approach and produces a uniform compost. In addition, pumps for insufflations is placed on mobile carts in order to reduce handling costs.

The plant is composed of the following parts: area for bulking agent storage (materials with structuring function such as pruning residues, wood chips, straw, etc.); area for mixing vegetable residues, bulking agents and starter; active compost pad; curing pad; screening compost and compost ready to use area; leachate detention pond (Figure 2). The plant is provided also with an irrigation system and an electricity network.

Agricultural crop residues, treated in the compost-on-farm plant, come from a door-to-door residue collection system from surrounding processing plants for fruit and vegetables adhering to the same consortium of producers and located at different distances from the composting plant. The final compost produced, about 9 tons per week, is used in agriculture by the consortium farms for the production of fruits and greenhouse vegetables.

\section{Materials and Methods}

The composting plant could treat around 2000 tons of vegetable biomass per year. One of the aims of the U.E. CarbOnFarm project is to involve more farms possible to create a network for the collection of these residues, to remedy the problems associated with their disposal and to produce and use compost on farm without resorting to the market. To encourage operators to implement the composting process it is fundamental to evaluate its environmental, energy, and economic sustainability. For this reason, two composting alternatives were taken into account within this study. The alternatives differed for the organic residues composted: in one case lettuce and other similar "light residues", in another case heavy biomass, as for example artichokes and cauliflowers residues, tomatoes' stems 
or walnut husks. The "light residues" are those with a dry matter content below $8 \%-10 \%$ while the "heavy materials" are those with a dry matter content above $10 \%$. The typology of composting material is very important because it influences the quantity of compost produced. Indeed, in the first case, called from now on "light compost" (LC), were produced 7.5 tons per week; in the second one, called from now on "heavy compost" (HC), were produced 10 tons per week.

As documented in the following sections, the same background conditions-namely the Functional Unit (FU) and the system boundaries-were defined for the development of the three sustainability assessments and, so, the same inventory data was collected and used.

\subsection{Environmental Analysis}

\subsubsection{Goal Definition, Functional Unit, and System Boundary}

The goal of the present analysis was to estimate and compare the environmental impacts of two composting alternatives (LC and HC) using the LCA methodology according to ISO 14040 and 14044 standards [48,49]. LCA is a methodology for determining the environmental impacts associated with a product, process or service from cradle to grave. The results obtained could be useful for farmers, farmer associations, technicians, and local politicians to solve the problems associated with agricultural wastes disposal through the sustainable production and usage of compost on-farm.

For the purpose of the current investigation, a ton of compost produced (with a $70 \%$ dry matter) was chosen as functional unit, namely the reference unit that expressed the function of the system in quantitative terms. At the same time, for the development of the whole assessment, the system boundary chosen was from the extraction of raw materials-passing through bulking agents processing (wood chip of pruning residues-PR), collection of the crop residues from farms, composting process-to final compost destination. As the Recycled Organics Unit [24] reported, a conventional composting system results in impacts and avoided impacts from a number of individual sub-systems. In this study, these sub-systems included the processing of the pruning residues; the transportation of these materials to the plant; the collection of crop residues and its receipt; the construction of the capital equipment and infrastructures; the compost processing and the transport and distribution on the field of the compost produced. In particular, the system boundary encompassed impacts associated with the construction of the capital equipment or infrastructures in all processes; the fuel usage in the various operations and the electricity used by the composting facility. System boundaries and input and output flows considered are depicted in Figure 3. 


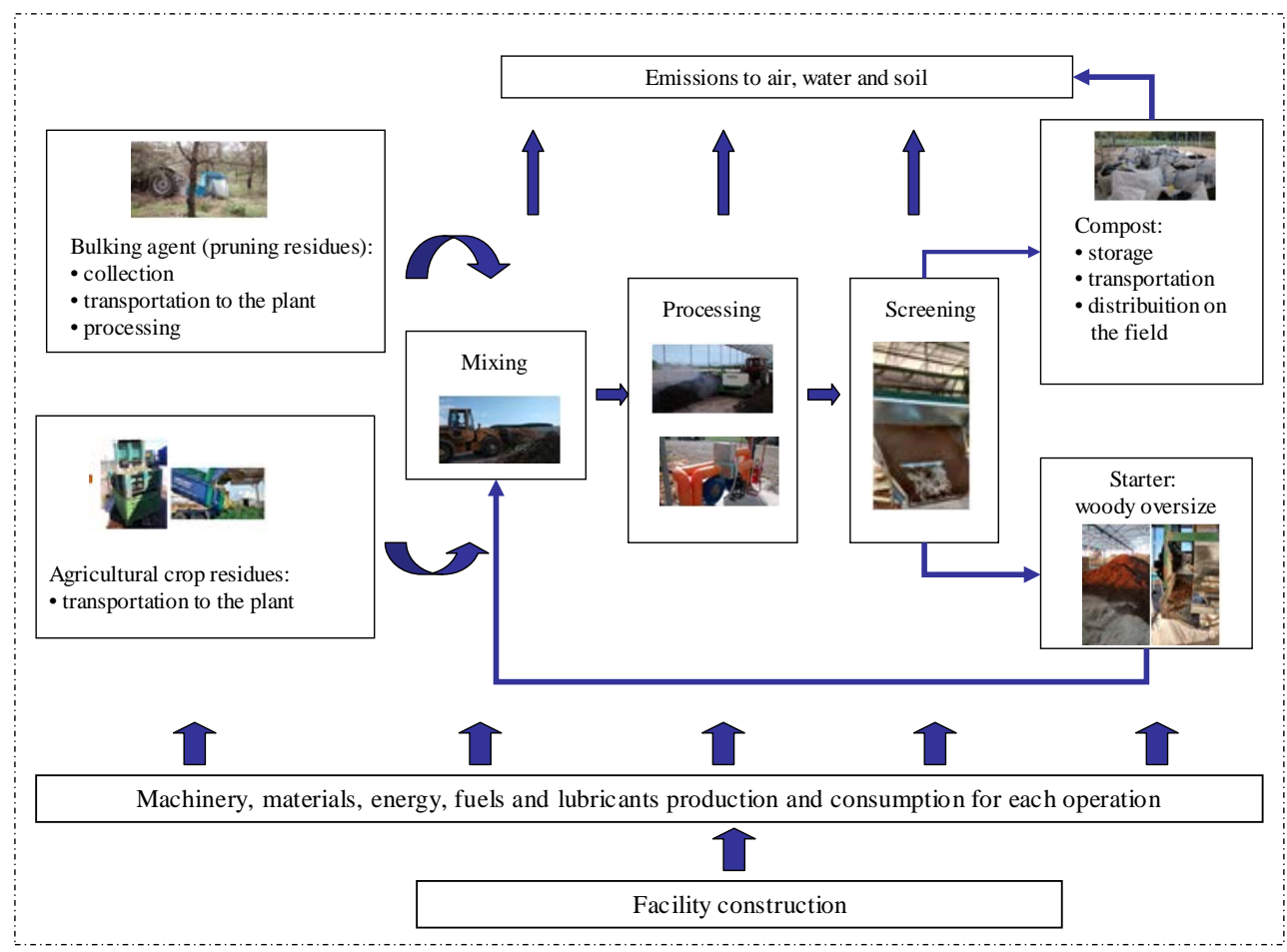

Figure 3. System boundary of the analysed compost production system.

\subsubsection{Data Collection and Life Cycle Inventory Analysis (LCIA)}

The inventory of the data associated to the studied systems was collected in situ, at the composting plant. Using a data collection sheet, information on the quantities of machinery, fuel, electricity, and other items used were gathered. All items and machinery used in the examined composting systems during the reference period (20 years) are reported in Tables 1 and 2.

Referring to the bulking agent processing, the following farming operations were taken into account: Manual collection of pruning residues from olive orchards, their transport to the composting plant and their chopping at the plant. With respect to the collection of biomasses to be composted, only their transport to the plant was taken into account.

For the construction of the composting facility the following operations were considered: building of composting and blending platform made of concrete; construction of covering structures made of steel and high-density polyethylene; forecourt made of gravel and other recycled materials; installation of irrigation system, air insufflation and electric systems made of concrete, polyvinylchloride, high-density polyethylene and other electronic components. The construction of the fence made of steel was considered too.

As in a similar study [38], data related to composting operational phases (days of treatment, aeration conditions, machinery, etc.) were also checked and confirmed in situ. The machineries taken into account are reported in Table 2. Particularly, the Iveco Eurocargo 120-230 was used for compost transport to the field, while-for the subsequent compost distribution-two tractors were taken into account: Antonio Carraro tgf 10,400, with manure spreader Mutti Amos S 35, and Fiat 640 D with front loader (Table 2).

In this study priority was given to using primary data in terms of input material typologies and amounts used. Additionally, as a standard practice in LCAs, secondary data were extrapolated from international databases of scientific importance and reliability, like the Ecoinvent 3 [50] and ELCD. In particular, this was done for the production of diesel, electricity, fertilizers used in the alternatives investigated, including the accounting of the resulting emissions, and the construction of the capital equipment. 
Table 1. Items used in the examined composting systems. Values per ton of compost. LC: light compost; HC: heavy compost.

\begin{tabular}{|c|c|c|}
\hline & LC & $\mathrm{HC}$ \\
\hline \multicolumn{3}{|l|}{ Collection of bulking agent } \\
\hline Bulking agent $\left(\mathrm{m}^{3}\right)$ & 2.67 & 2.00 \\
\hline Machinery (h) & 8.80 & 6.60 \\
\hline Diesel and Lubricants (MJ) & 56.91 & 42.68 \\
\hline Electricity $(\mathrm{kWh})$ & 1.48 & 1.11 \\
\hline Human labor (h) & 2.93 & 2.20 \\
\hline \multicolumn{3}{|l|}{ Collection of crop residues } \\
\hline Agricultural residues $\left(\mathrm{m}^{3}\right)$ & 26.67 & 10.00 \\
\hline Machinery (h) & 2.13 & 0.80 \\
\hline Diesel and Lubricants (MJ) & 13.28 & 4.98 \\
\hline Electricity (kWh) & 1.65 & 1.24 \\
\hline Human labor (h) & 2.93 & 1.10 \\
\hline \multicolumn{3}{|l|}{ Construction of the facility } \\
\hline Steel hot dip galvanized $(\mathrm{kg})$ & 2.00 & 1.50 \\
\hline Concrete, normal (kg) & 142.53 & 106.90 \\
\hline Reinforcing steel (kg) & 3.47 & 2.60 \\
\hline Sand $(\mathrm{kg})$ & 24.33 & 18.25 \\
\hline Polyethylene high density (kg) & 0.16 & 0.12 \\
\hline Recycled material (kg) & 269.20 & 201.90 \\
\hline Gravel (kg) & 23.08 & 17.31 \\
\hline Polyvinylchloride (kg) & 30.88 & 23.16 \\
\hline Concrete block (kg) & 2.57 & 1.93 \\
\hline Pig iron (kg) & 0.32 & 0.24 \\
\hline Cable (kg) & 0.02 & 0.02 \\
\hline Polyurethane (kg) & 0.05 & 0.04 \\
\hline Electronics components (kg) & 0.01 & 0.01 \\
\hline Machinery (h total) & 112.93 & 84.70 \\
\hline Diesel and Lubricants (MJ total) & 36072.93 & 27054.70 \\
\hline Human labor (h total) & 206.27 & 154.70 \\
\hline \multicolumn{3}{|l|}{ Composting process } \\
\hline Machinery (h) & 9.73 & 7.70 \\
\hline Diesel and Lubricants (MJ) & 323.73 & 213.60 \\
\hline Electricity (kWh) & 17.70 & 14.28 \\
\hline Human labor (h) & 4.33 & 3.25 \\
\hline \multicolumn{3}{|c|}{ Transport of the compost and its distribution on the field } \\
\hline Machinery (h) & 3.68 & 3.68 \\
\hline Diesel and lubricants (MJ) & 201.18 & 201.18 \\
\hline Human labor (h) & 1.06 & 1.06 \\
\hline
\end{tabular}


Table 2. Machineries used in the examined composting systems.

\begin{tabular}{|c|c|}
\hline Operation & Machinery \\
\hline \multirow{3}{*}{ Construction of the facility } & Concrete mixer truck Mercedes 2635 \\
\hline & Excavator Hitachi $85 \mathrm{q}$ \\
\hline & Tipper lorry Iveco 330-35 \\
\hline \multirow{2}{*}{ Collection of bulking agents } & Truck Deuz Fahr Agrofarm 420 \\
\hline & Chipper Pezzolato S 7000 \\
\hline Collection of crop residues & Truck Iveco Eurocargo 120-230 \\
\hline \multirow{4}{*}{ Composting process } & Turned-windrows Pezzolato prt 2500 \\
\hline & Tractor Deuz Fahr Agrofarm 420 \\
\hline & 4 blowers $\mathrm{Mz}$ Vm 400/N2 \\
\hline & Shovel Fiat Allis FR 10b \\
\hline Transport of the compost to the field & $\begin{array}{l}\text { Homemade compost screener with tape loader } \\
\text { working } 1.5 \mathrm{t} \text { of compost per hour }\end{array}$ \\
\hline \multirow[t]{2}{*}{ Distribution of the compost on the field } & $\begin{array}{l}\text { Tractor Carraro tgf 10,400 with manure spreader Mutti } \\
\text { Amos S } 35\end{array}$ \\
\hline & Tractor Fiat 640 D with front loader \\
\hline
\end{tabular}

Referring to electricity, the dataset describes the transformation from medium to low voltage, as well as the distribution of electricity at low voltage. In particular, it encompasses the electricity production in Italy and from imports, the transmission network as well as direct emissions to air. Also, electricity losses during low-voltage transmission and transformation from medium voltage were accounted for [50]. The fuel consumption model included the transportation of the product from the refinery to the end user. The inventory of agricultural vehicles took only into account the use of resources and the amount of emissions during their production, maintenance, repair, and final disposal. Of all items considered, only the production of the sand utilized into the construction of the plant was excluded due to the absence of the production processes of this material in the databases, but was considered its transport to the plant.

Composting is an aerobic process in which microorganisms transform organic substrates into a stable, humus-like material [6]. Stability of the final compost is a key factor in order to consider compost as a suitable material for soil amendment or/and as a mineral fertilizer substitute [7]. During composting process, many types of gaseous compounds such as GHGs (i.e., $\mathrm{CH}_{4}, \mathrm{~N}_{2} \mathrm{O}, \mathrm{CO}_{2}$ ) and $\mathrm{NH}_{3}$ are directly released into the atmosphere. As in similar studies [9], only emissions of $\mathrm{CH}_{4}, \mathrm{NH}_{3}$ and $\mathrm{N}_{2} \mathrm{O}$ have been considered in the present study since they represent, together with $\mathrm{CO}_{2}$ and VOCs, $99 \%$ of the total emission [29,51,52]. In accordance with the recommendation of the Intergovernmental Panel on Climate Change [53] and other authors of studies on composting LCAs [7,9,29-31,54-56], $\mathrm{CO}_{2}$ emitted from composting is biogenic and not fossil-derived, so it was not considered as a greenhouse gas emission and not included in the global warming potential (GWP) accounting.

The emissions of $\mathrm{CH}_{4}, \mathrm{NH}_{3}$ and $\mathrm{N}_{2} \mathrm{O}$ were not experimentally measured, but values were taken from a literature review (Table 3), considering only studies similar to the present study for composted material and technology used. At the same time, it is impossible to find emission values perfectly adaptable to this study since these emissions are caused by the decomposition of organic residues which is affected by several factors occurring during composting process (aeration rate, water content, thermal insulation, weather conditions, substrate composition, etc.) and whose measurement is not easy. However, the average emission values from our literature review used in the analysis were $0.24 \mathrm{~kg}$ of $\mathrm{CH}_{4} ; 0.14 \mathrm{~kg}$ of $\mathrm{NH}_{3}$ and $0.12 \mathrm{~kg}$ of $\mathrm{N}_{2} \mathrm{O}$ per ton of feedstock (Table 3). 
Table 3. Literature review of compost emissions ( $\mathrm{kg}$ per ton of raw material).

\begin{tabular}{ccccc}
\hline References & Composted Material & $\mathbf{C H}_{\mathbf{4}}$ & $\mathbf{N H}_{\mathbf{3}}$ & $\mathbf{N}_{\mathbf{2}} \mathbf{O}$ \\
\hline$[57]$ & $\begin{array}{c}\text { Household organic waste with leaves, grass } \\
\text { clippings and bush trimmings }\end{array}$ & 0.17 & - & 0.022 \\
\hline$[58]$ & Household organic waste with leaves and branches & 0.20 & - & 0.11 \\
\hline$[59]$ & Household organic waste with leaves and branches & 0.08 & - & 0.04 \\
\cline { 3 - 5 } & \multirow{2}{*}{ Green waste } & 0.30 & - & 0.1 \\
\hline$[29]$ & Bio and green waste & 0.05 & 0.025 & 0.025 \\
\hline$[29]$ & Leftover of fruit and vegetables & 0.60 & 0.354 & 0.178 \\
\hline$[43]$ & & 1.52 & - & 0.252 \\
\hline Average & & 0.30 & 0.03 & 0.2 \\
\hline
\end{tabular}

\subsubsection{Life Cycle Impact Assessment}

The SimaPro v. 8.04 software [60] was used to determine the environmental impacts of the examined composting systems during a reference period of 20 years (corresponding to the lifespan of the plant). The impact assessment was performed following the problem-oriented LCA method CML 2001 developed by the Centre of Environmental Science of Leiden University [61].

According to similar studies [62-66], the following impact categories were selected for this research [67]:

- Abiotic depletion (AD), the main concern of this category is the health of humans and the ecosystem and how it is affected by the extraction of minerals and fossil fuels, which are inputs into the system. For each extraction of minerals and fossil fuels, the abiotic depletion factor is determined. This indicator is on a global scale and is based on the concentration reserves and rate of deaccumulation.

- Acidification (AA), acidifying substances cause a wide range of impacts on soil, groundwater, surface water, organisms, ecosystems, and materials. The measure $\mathrm{SO}_{2}$ equivalent $/ \mathrm{kg}$ emission was used to express the AA. This category has a geographical scale that can be local and global.

- $\quad$ Eutrophication (EP), considers the impact of excessive levels of macronutrients in the environment caused by emissions of nutrients to air, water, and soil. The stoichiometric procedure of Heijungs is the basis of the $\mathrm{EP}$, which is expressed as the mass of $\mathrm{PO}_{4}$ equivalents per kilogram of emission. The geographical scale varies between local and continental, the time span is infinite, and fate and exposure are not included.

- Global warming (GWP), greenhouse gas emissions to air are related to the climate change. Adverse effects upon ecosystem health, human health, and material welfare can result from climate change. The Intergovernmental Panel on Climate Change developed a characterization model that is used to develop characterization factors. A measure of the mass of carbon dioxide per kilogram of emission is used to express the global warming potential for a time horizon of 100 years (GWP100). This indicator is on a global scale.

- $\quad$ Ozone layer depletion (OLD), stratospheric ozone depletion potential accounts for impacts related to the reduction of the protective ozone layer within the stratosphere caused by emissions of ozone depleting substances (CFCs, HFCs, and halons). The ozone depletion potential of each of the contributing substances is characterized relative to CFC-11, with the final impact indicator indicating mass (e.g., $\mathrm{kg}$ ) of equivalent CFC-11;

- $\quad$ Photochemical oxidation (PO), is secondary air pollution, also known as summer smog. It is the formed in the troposphere caused mainly by the reaction of sunlight with emissions from fossil fuel combustion creating other chemicals. It is expressed as kg ethylene equivalents. 
Furthermore, the impact assessment was conducted using a midpoint approach so using equivalent indicators (specific for the impact categories considered) to express the LCA results in the form of characterization values. In order to assess the contribution of each impact category on the overall environmental problem, 'Normalization' of the characterization results was done using as "Normal" value for the region "Europe 25" [60].

\subsection{Energy Analysis}

Following Namdari et al. [68], the energy analysis (EA) technique was used to calculate the energy involved in the production of 1 ton of the compost. To combine the EA results with those coming from the LCA, the analysis was conducted with the same system boundary and the same life cycle inventory described for LCA. The data collected covered the duration of each operation and the quantities of each input (machinery, fuel, electricity, labor, etc.). Energy values of unit inputs were given in mega joules (MJ) by multiplying each input by its own coefficient of equivalent energy factors taken from the literature. Specifications are reported in Pergola et al. [32].

\subsection{Life Cycle Costing}

The production costs of the compost were analyzed according to the Life Cycle Costing (LCC) methodology, through repayment of the capital cost of the facility (annualized over 20 years at an assumed $2 \%$ interest rate) plus operating and maintenance costs [69]. Similar to the EA, in order to join LCC and LCA findings, the analysis was performed using the same system boundary and life cycle inventory described for LCA. Specifications can be found in Pergola et al. [32].

\section{Results and Discussion}

\subsection{Environmental Aspects}

Table 4 shows the total life cycle impacts in the reference period (20 years) and impacts per ton of the compost produced by the two analyzed composting alternatives. After 20 years of working, in our experimental conditions, the construction of the facility, the collection of the bulking agent and the crop residues, the process, the transport of the compost to the field and its distribution, plus direct emissions produced during the decomposition phases, could cause an abiotic depletion (AD) equal to $44 \mathrm{~kg}$ of $\mathrm{Sb}$; a global warming potential (GWP) between 1,668,000 and 1,678,000 $\mathrm{kg}$ of $\mathrm{CO}_{2 \mathrm{eq}}$; an average ozone layer depletion (ODP) of $0.13 \mathrm{~kg}$ of $\mathrm{CFC}_{-11 \text { eq; }}$; photochemical oxidation (PO) from 613 to $620 \mathrm{~kg}$ of $\mathrm{C}_{2} \mathrm{H}_{4} \mathrm{eq}$; an air acidification (AA) between 14,558 to $14,581 \mathrm{~kg}$ of $\mathrm{SO}_{2}$ eq; and an average eutrophication potential (EP) about of $5965 \mathrm{~kg}$ of $\mathrm{PO}_{4-\text { eq }}$ (Table 4).

The typology of composted material during the lifespan of the plant will determine the type and the quantity of the compost produced, and consequently the impacts generated per ton of the compost, as reported in Table 4. The main differences between the two alternatives could be found in the collection of crop residues, the composting process, the final transport of the compost and its distribution on the field. Regarding the first operation, the LC consisting of fresh material rich in water (lettuce, rocket salad, and so on) involved more transportation of raw materials and fuel consumption to create the piles (one pile is about $200 \mathrm{~m}^{3}$ of raw materials). Instead, concerning the composting process, the lower volumes of raw materials involved in HC (one pile is about $100 \mathrm{~m}^{3}$ of raw materials), determined minor impacts in this alternative since there was less use of machinery and fuel in the operations of mixing compostable materials and bulking agent and in the creation of the piles. On the contrary, the higher yields of the HC (about $20 \mathrm{~m}^{3}$ of compost per pile) led to the highest impacts in the transport and distribution of this type of the compost. 
Table 4. Results of the total life cycle impact assessment in the reference period (20 years) and per ton of compost. Light Compost (LC); heavy Compost (HC). Values are expressed in tons.

\begin{tabular}{|c|c|c|c|c|c|c|c|c|c|c|c|c|}
\hline & \multirow{2}{*}{\multicolumn{2}{|c|}{$\frac{\mathrm{AD}}{\mathrm{Sb} \text { eq }}$}} & \multirow{2}{*}{\multicolumn{2}{|c|}{$\begin{array}{c}\mathrm{GWP} \\
\mathrm{CO}_{2} \mathrm{eq}\end{array}$}} & \multirow{2}{*}{\multicolumn{2}{|c|}{$\begin{array}{c}\text { OLD } \\
\text { CFC-11eq }\end{array}$}} & \multirow{2}{*}{\multicolumn{2}{|c|}{$\begin{array}{c}\mathrm{PO} \\
\mathrm{C}_{2} \mathrm{H}_{4} \mathrm{eq}\end{array}$}} & \multirow{2}{*}{\multicolumn{2}{|c|}{$\frac{\mathrm{AA}}{\mathrm{SO}_{2} \mathrm{eq}}$}} & \multirow{2}{*}{\multicolumn{2}{|c|}{$\frac{\mathrm{EP}}{\mathrm{PO}_{4}-\mathrm{eq}}$}} \\
\hline & & & & & & & & & & & & \\
\hline & LC & HC & LC & $\mathrm{HC}$ & LC & HC & LC & $\mathrm{HC}$ & LC & HC & LC & $\mathrm{HC}$ \\
\hline Construction of the facility & 0.0 & 0.0 & 333 & 333 & 0.0 & 0.0 & 0.1 & 0.1 & 1.4 & 1.4 & 0.3 & 0.3 \\
\hline Collection of bulking agent & 0.0 & 0.0 & 245 & 245 & 0.0 & 0.0 & 0.1 & 0.1 & 1.4 & 1.4 & 0.4 & 0.4 \\
\hline Collection of crop residues & 0.0 & 0.0 & 92 & 46 & 0.0 & 0.0 & 0.0 & 0.0 & 0.6 & 0.3 & 0.2 & 0.1 \\
\hline Composting process & 0.0 & 0.0 & 724 & 704 & 0.0 & 0.0 & 0.4 & 0.4 & 9.4 & 9.2 & 4.5 & 4.5 \\
\hline $\begin{array}{l}\text { Transport of the compost } \\
\text { and its distribution }\end{array}$ & 0.0 & 0.0 & 229 & 306 & 0.0 & 0.0 & 0.1 & 0.1 & 1.5 & 2.0 & 0.4 & 0.5 \\
\hline Direct emissions & 0.0 & 0.0 & 43 & 43 & 0.0 & 0.0 & 0.0 & 0.0 & 0.2 & 0.2 & 0.1 & 0.1 \\
\hline Total at the 20th year & 0.0 & 0.0 & 1668 & 1678 & 0.0 & 0.0 & 0.6 & 0.6 & 14.6 & 14.6 & 6.0 & 6.0 \\
\hline Impact per ton & 0.0 & 0.0 & 0.214 & 0.161 & 0.0 & 0.0 & 0.0 & 0.0 & 0.0 & 0.0 & 0.0 & 0.0 \\
\hline
\end{tabular}

Data normalization reported in Figure 4 shows that in both alternatives the major impacts affected the following categories: Acidification (27\%); eutrophication (22\% in LC and $23 \%$ in HC); abiotic resource depletion ( $21 \%$ in LC and $20 \%$ in $\mathrm{HC}$ ); and global warming (20\% in LC and $21 \%$ in $\mathrm{HC}$ ).

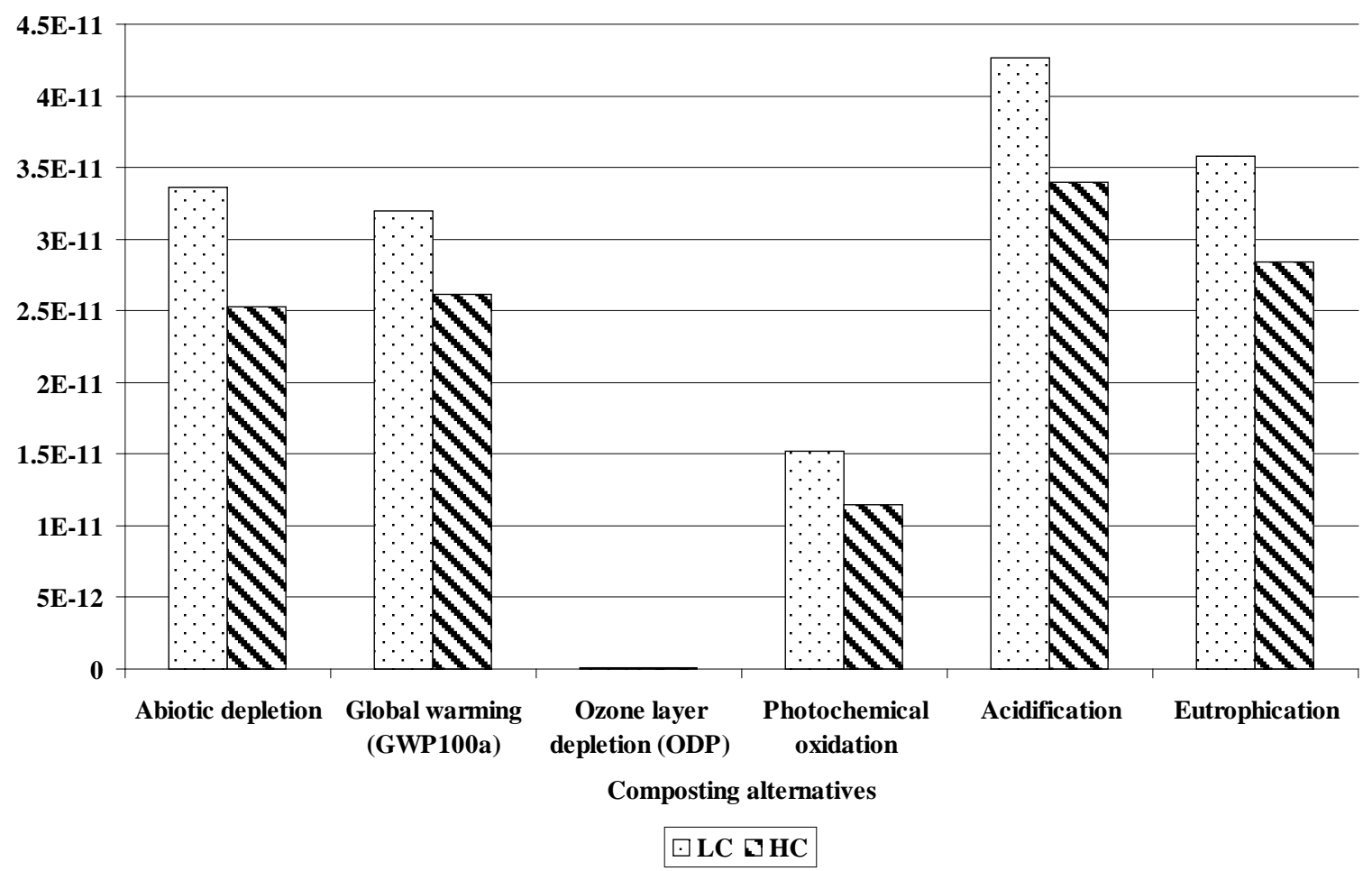

Figure 4. Normalization of the impact categories of the examined composting systems. Values per ton of compost. Light compost (LC); heavy compost (HC).

Figure 5 reports the contribution of the single operations and the direct emissions to the impact categories and shows that the composting process had the greatest impact in all categories, above all in $\mathrm{AD}$ in which it represented, on average, $87 \%$. Its greatest impact was due to the electricity consumed in the insufflation phase (about $138 \mathrm{kWh}$ per pile). Direct emissions, when present, were the second most important item with an average contribution of 12\% (in EP), 13\% (in AA), and 19\% (in GWP), but these are only assumptions since they were not experimentally measured. 

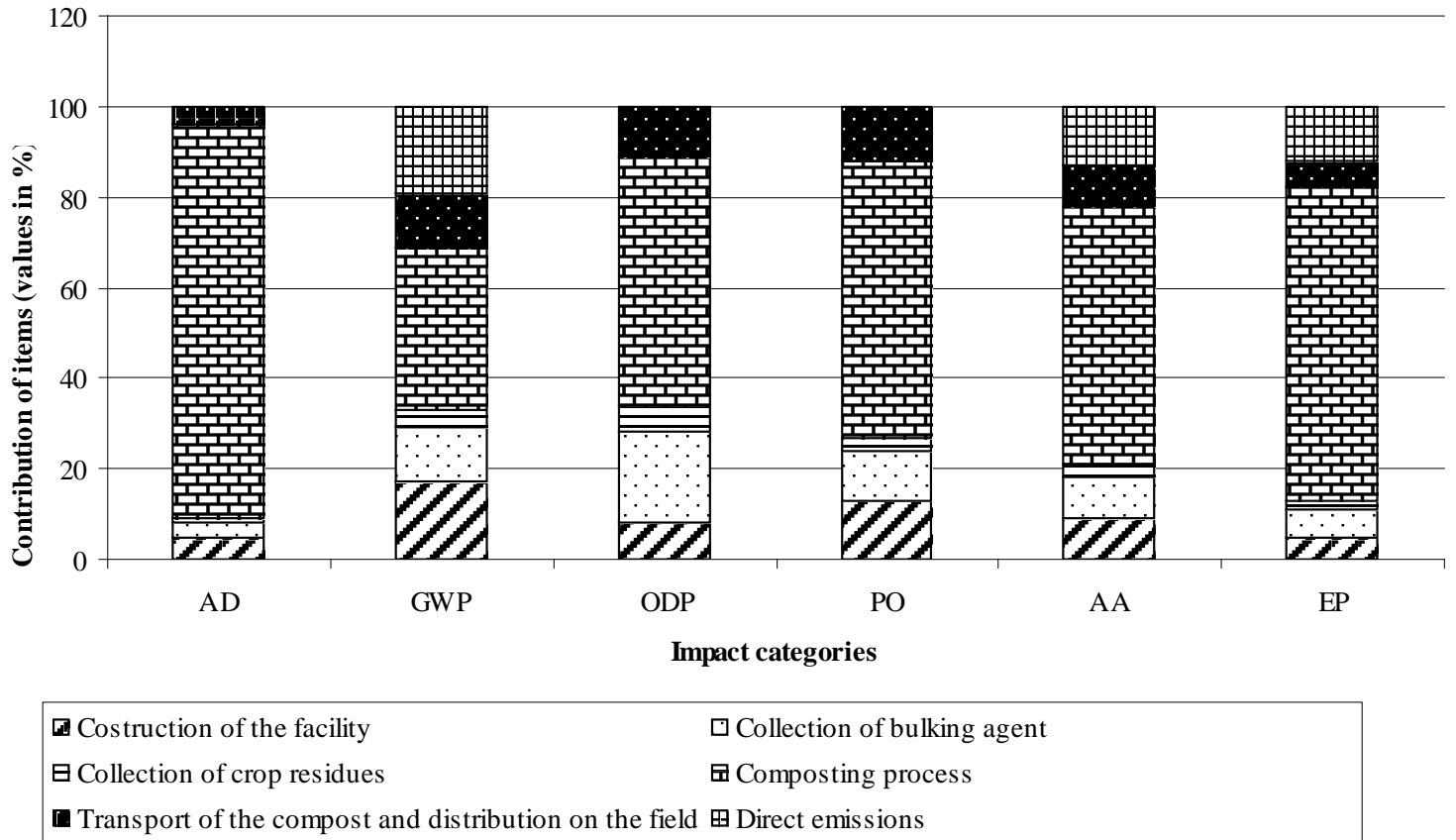

- Transport of the compost and distribution on the field $\boxplus$ Direct emissions

Figure 5. Contribution of the operations and the direct emissions to the impact categories per ton of compost (average between the two composting alternatives). Abiotic depletion (AD); global warming potential (GWP); ozone layer depletion (ODP); photochemical oxidation (PO); air acidification (AA); eutrophication potential (EP).

From the premise that there are not references in literature on the environmental impacts occurring during the on-farm composting of "green waste" by means of open windrow systems, there are some differences between our results and those few found in other similar studies, as reported in Table 5. This was due to the different characterization method used in the LCA analysis and to the system boundaries considered.

Table 5. Literature review of global warming potential and energy consumption (values per ton of raw materials).

\begin{tabular}{|c|c|c|c|c|}
\hline References & Composted Materials & Technology & $\begin{array}{c}\mathrm{kg} \\
\mathrm{CO}_{2} \mathrm{eq}\end{array}$ & MJ \\
\hline Our case study & light residues of agricultural crops & windrows composting & 39.05 & 372.79 \\
\hline Our case study & heavy residues of agricultural crops & windrows composting & 37.45 & 373.48 \\
\hline$[64]$ & bio-waste & composting & 130 & - \\
\hline [62] & OFMSW & tunnel composting & 63.90 & - \\
\hline [62] & OFMSW & confined windrows composting & 63.15 & - \\
\hline [43] & leftovers of raw fruit and vegetables & home composting & 82.60 & 468 \\
\hline [42] & OFMSW & home composting & 220 & 351 \\
\hline [42] & OFMSW & industrial composting & 153 & 1908 \\
\hline [7] & bio-waste & home composting $\mathrm{LE}^{\mathrm{a}}$ & 16.03 & - \\
\hline [7] & bio-waste & home composting $\mathrm{HE}^{\mathrm{b}}$ & 87.94 & - \\
\hline [9] & food waste & composting with minimum d.e.s. $^{c}$ & 1548 & - \\
\hline [9] & food waste & composting with average d.e.s. ${ }^{c}$ & 5525 & - \\
\hline [9] & food waste & composting with maximum d.e.s. ${ }^{c}$ & 24250 & - \\
\hline
\end{tabular}


Referring only to global warming, in our experimental conditions the production of 1 ton of LC caused an emission of $250 \mathrm{~kg}$ of $\mathrm{CO}_{2} \mathrm{eq}$; while the production of 1 ton of $\mathrm{HC}$ caused an emission of $199 \mathrm{~kg}$ of $\mathrm{CO}_{2}$ eq. Diacono et al. 2019 [70], using anaerobic digestate from cattle manure, reported a cumulative emission of about $31.4 \mathrm{~kg} \mathrm{CO}_{2} \mathrm{eq} \mathrm{ton}^{-1}$ under an aerated composting process. This value is lower if compared to ours due mostly to the raw materials used in the different studies (particularly, low dry matter content of green waste utilized in this study). Considering the carbon fixed in the compost, that it is equal to the $\mathrm{C}-\mathrm{CO}_{2}$ sequestered by the agricultural compostable residues and on average equal to 1.468 kilograms per $\mathrm{kg}$ of compost (considering a $\mathrm{C}$ content of $40 \%$ ), it can be stated that the production of 1 ton of LC was responsible for the emission of $17 \%$ of this carbon prior sequestered, while in $\mathrm{HC}$ this ratio was $13 \%$.

\subsection{Energy Consumptions}

The energy analysis showed that the construction of the facility and its use for a period of 20 years could cause an energy consumption more than 15,500 GJ, translating into an annual energy consumption of approximately $775 \mathrm{GJ}$ (Table 6). In both composting alternatives the construction of the plant was the item that consumed the largest amount of energy used (38\%), followed by the composting process (27\%) (Figure 6). In the first item, the concrete was the highest energy input representing 53\% of the energy involved in the construction of the facility. On the contrary, in the composting process the highest energy input was shown by diesel fuel and lubricants used above all in the mixing of the bulking agent with compostable crop residues, in the creation of the pile and during the screening of the compost obtained. From the above, it is clear that in both composting alternatives has been used a little more indirect energy (relative to materials and machinery) than direct (human labor, electricity, diesel fuel and lubricants) and $99 \%$ of the total energy used was a non-renewable energy form (Table 7).

Table 6. Energy consumption for the examined composting alternatives in the reference period (20 years) and per ton of compost.

\begin{tabular}{ccc}
\hline & \multicolumn{2}{c}{ Energy Consumptions (MJ) } \\
\hline Construction of the facility & LC & HC \\
\hline Collection of bulking agents & $5,851,605$ & $5,851,605$ \\
\hline Collection of crop residues & $2,360,958$ & $2,360,958$ \\
\hline Composting process & $1,225,719$ & 612,860 \\
\hline Transport of the compost and its distribution & $4,145,301$ & $4,145,301$ \\
\hline Total energy input at the 20th year & $\mathbf{1 5 , 5 0 8 , 0 0 8}$ & $\mathbf{1 5 , 5 3 6 , 6 2 4}$ \\
\hline Annual energy input & $\mathbf{7 7 5 , 4 0 0}$ & $\mathbf{7 7 6 , 8 3 1}$ \\
\hline Energy consumption per ton & $\mathbf{1 9 8 8}$ & $\mathbf{1 4 9 4}$ \\
\hline
\end{tabular}




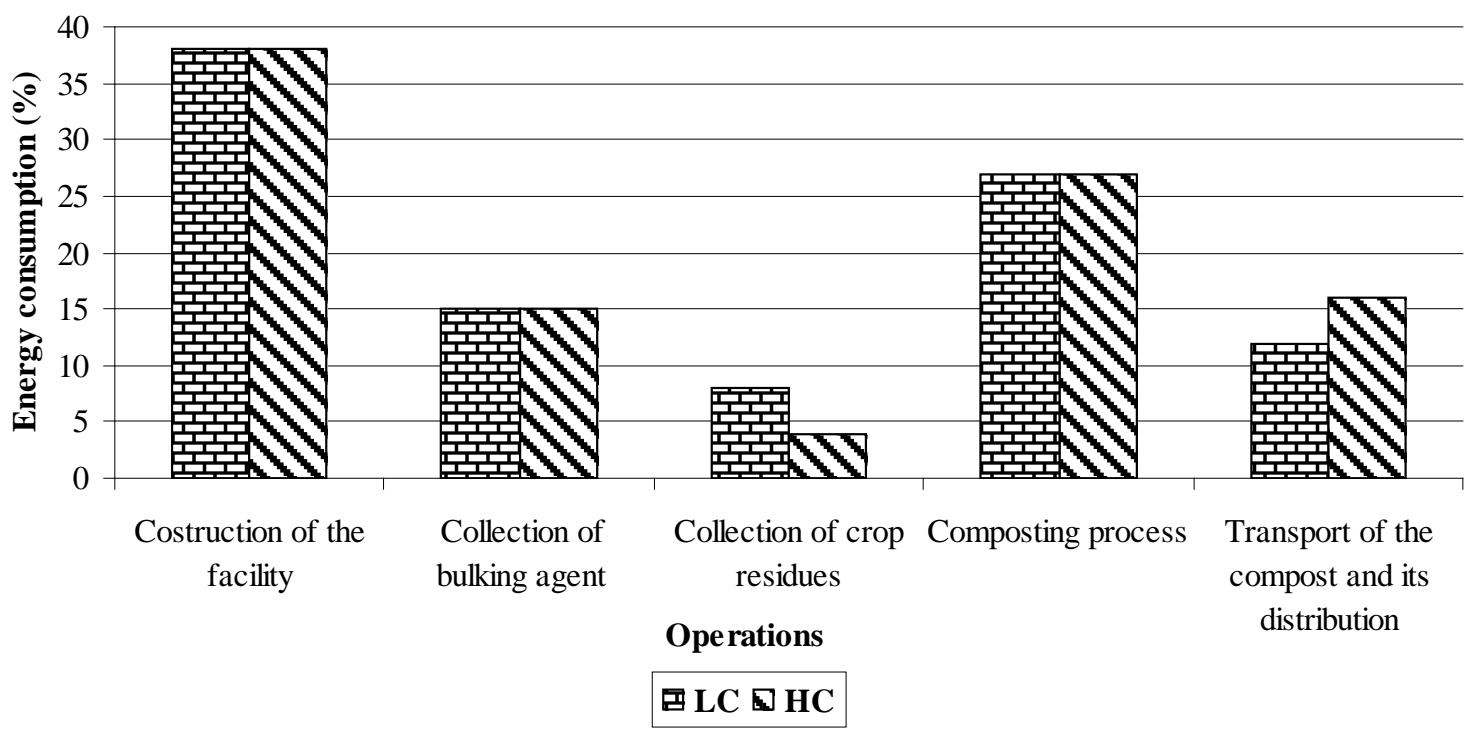

Figure 6. Energy consumption of the examined composting alternatives in the reference period (20years). Light compost (LC); heavy compost (HC).

Table 7. Some energy forms for composting production under the two alternatives in the reference period (20 years). Values in MJ and \%. Light compost (LC); heavy compost (HC).

\begin{tabular}{ccccc}
\hline & \multicolumn{3}{c}{ Composting Alternatives } \\
\hline \multicolumn{2}{c}{ LC } & \multicolumn{2}{c}{ HC } \\
\hline Direct energy & $6,765,093$ & $44 \%$ & $6,173,869$ & $40 \%$ \\
\hline Indirect energy & $8,742,915$ & $56 \%$ & $9,362,755$ & $60 \%$ \\
\hline Renewable energy & 171,868 & $1 \%$ & 151,044 & $1 \%$ \\
\hline Non-renewable energy & $15,336,140$ & $99 \%$ & $15,385,580$ & $99 \%$ \\
\hline Total energy input at the 20th year & $\mathbf{1 5 , 5 0 8 , 0 0 8}$ & $\mathbf{1 0 0} \%$ & $\mathbf{1 5 , 5 3 6 , 6 2 4}$ & $\mathbf{1 0 0} \%$ \\
\hline
\end{tabular}

The production of 1 ton of LC involved the consumption of about $2000 \mathrm{MJ}$ of energy, while the production of compost from "heavy" crop residues required $1494 \mathrm{MJ}$ of energy per ton. This difference was largely due to the different yields that characterized the two types of compost.

According to the literature review reported in Table 5, our energy results per ton of feedstock was similar to other studies on home composting [42,43] and lower than energy consumptions found in the industrial composting [43]. This last finding was essentially due to the higher amount of indirect energy involved in the construction of the facility and during the composting process under industrial conditions.

\subsection{Cumulative Production Costs}

The life cycle costs methodology was performed to analyze the costs to produce a LC and a HC in order to better evaluate the sustainability of the studied on-farm composting plant. The cumulative total cost at the 20th year of working of the plant will be equal to 1,629,840 euro if the compostable material is light and equal to 1,314,768 euro if the crop residues are heavy (Table 8). This finding was due to differences in the residues quantity to collect for piles creation (200 cubic meters per pile in LC versus 100 cubic meters per pile in $\mathrm{HC}$ ) and in the transport and distribution of the compost produced (15 cubic meters per pile in LC versus 20 cubic meters per pile in HC). 
Table 8. Production costs for the examined composting alternatives in the reference period (20 years) and per ton of compost. Light compost (LC); heavy compost (HC).

\begin{tabular}{ccc}
\hline Capital costs (€) & LC & HC \\
\hline Construction of the facility & 232,772 & 232,772 \\
\hline Machines & 29,934 & 29,934 \\
\hline Insurance and maintenance fees & 928 & 928 \\
\hline Operation costs (€) & \\
\hline Collection of bulking agents & 230,606 & 230,606 \\
\hline Collection of crop residues & 675,729 & 337,865 \\
\hline Composting process & 364,679 & 356,635 \\
\hline Transport of the compost and its distribution & 95,192 & 126,029 \\
\hline Total at the 20th year & $\mathbf{1 , 6 2 9 , 8 4 0}$ & $\mathbf{1 , 3 1 4 , 7 6 8}$ \\
\hline Costs per ton & $\mathbf{1 6 2}$ & $\mathbf{9 8}$ \\
\hline
\end{tabular}

With regard to the single cost, in LC around $40 \%$ of total costs $(675,729 €)$ were related to the collection of crop residues, while in HC these costs were only the $27 \%(337,865 €)$. Indeed, in HC there was not a single major cost, but there were three most important costs: The composting process $(27 \%)$; the collection of crop residues (26\%); and the capital costs $(20 \%)$. The analysis of the distribution of the production factors in composting production (Figure 7) suggested that in both alternatives, the highest cost was provided by labor (more than $40 \%$ ) followed by electricity (about $30 \%$ ). In this case too, the quantity of the compost produced defines the cost per ton, which was equal to $162 €$ ton $^{-1}$ in LC and $98 €$ ton $^{-1}$ in HC (Table 8). These results show how HC had a lower rate of overall costs than LC, and it appears to be twice as sustainable due to the lower costs in total and per ton of compost produced.

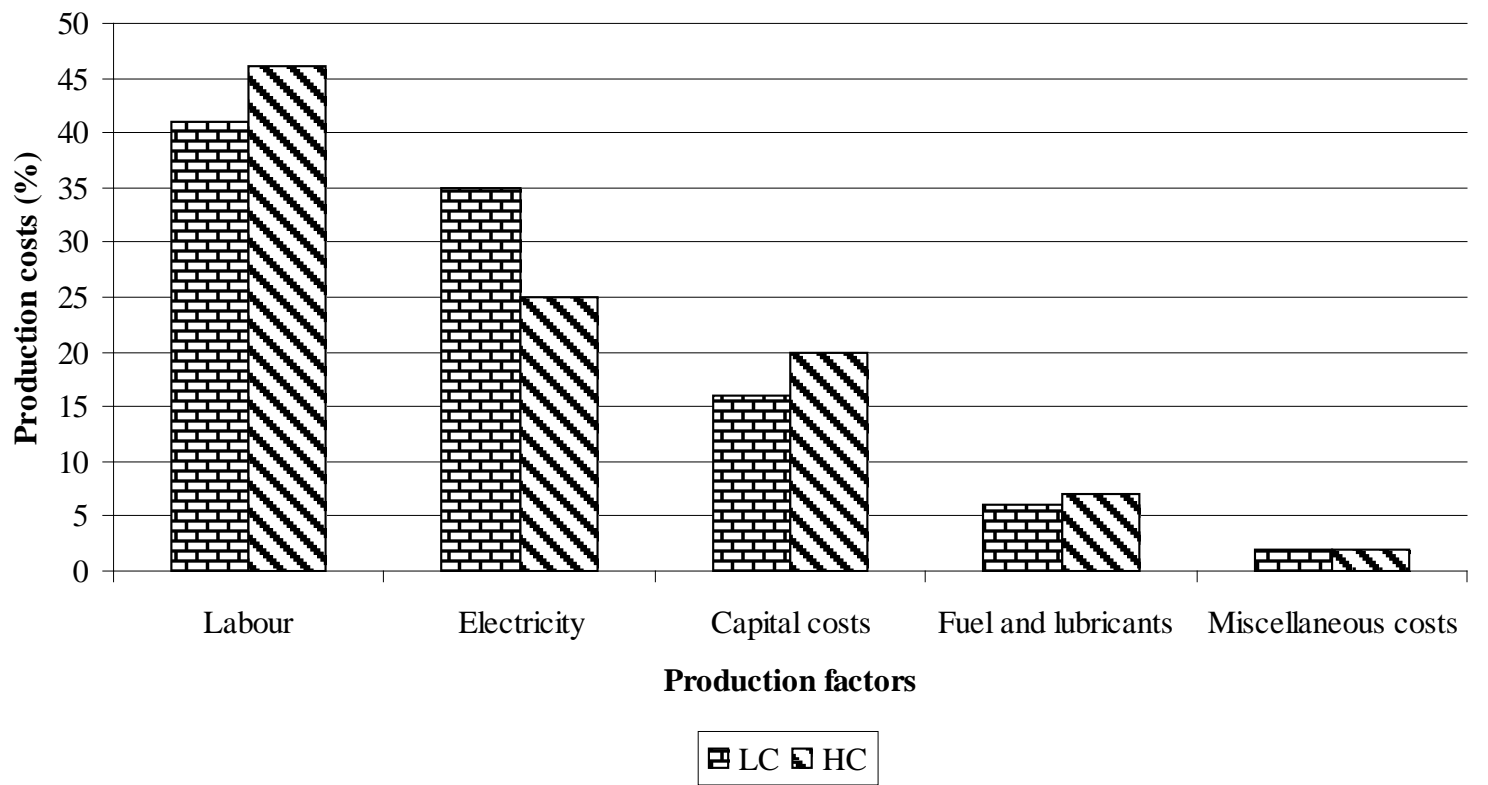

Figure 7. The contribution of the production factors to the total costs in the reference period (20 years).

Light compost (LC); heavy compost (HC).

From an economic point of view, the production of on-farm compost certainly has a cost, but the motivation for farmers to produce this compost is high, since it eliminates costs associated with disposal of growing volumes of residues of agricultural crops; the use of composted products in 
agriculture reduces the use of fertilizers and herbicides and consequently their costs in farm balance; organic mulches can reduce cultivation costs by $20 \%-40 \%[70,71]$; the increasing water use efficiency leads to the reduction of irrigation costs.

\section{Conclusions and Future Perspectives}

The agricultural waste products by horticultural farms are generally problematic to manage, especially in areas where production is intensive and under greenhouse. But they can be appropriately valorized by addressing them in a virtuous compost chain. In fact, through the realization of an on-farm composting plant, it is possible to produce a quality compost, usable as a production factor on the holding itself, with the further advantage to close the carbon cycle and, at the same time, solve the problem of disposing large volumes of agricultural waste.

The adoption of the composting techniques by farmers requires however an evaluation of its environmental, energy, and economic cost, in particular as regards the construction of the facility and its management. The results of these evaluations are fundamental elements for a comprehensive assessment of the sustainability of the compost and, thanks to their reliability, can be easily accessed and used by farmers, farmer associations, technicians, and local politicians to develop improved agricultural waste management systems.

Under our experimental conditions, the production of 1 ton of compost on-farm from light and heavy raw materials caused a $\mathrm{CO}_{2} \mathrm{eq}$ emission of 199 and $250 \mathrm{~kg}$, an energy requirement of 1500 and $2000 \mathrm{MJ}$, and a cost of 98 and 162 euro, respectively. It is evident that the production of compost from "heavy" materials is more sustainable, but the production costs make both HC and LC cheaper than the commercial compost, with similar characteristics, affordable on the Italian market. Furthermore, most likely, if the analysis considers the missed costs due to the ordinary management of agriculture residues - as the field disposal — and to the reduced use of fertilizers and irrigation water, the adoption on farm of this composting technology would still be more sustainable. Therefore, to test this, it should be appropriate to analyze the farm in its entirety and make assessments on different scales: Large consortia of farms (as the case described here), medium, and small (a single farm).

It is important to promote, in as many farms as possible, the diffusion of these low technology composting processes for the reuse of different organic matrices within the farm itself (usually considered as wastes) and the agronomical use of compost thus obtained. Using compost is accompanied by other key benefits and environmental significance such as improved sanitary conditions of soils; reduced crop residue costs management; enhanced soil carbon sequestration by farms; and reduced external inputs such as fertilizers, pesticides and water.

Author Contributions: Conceptualization, M.P. and G.C.; Methodology, A.P. and M.P.; Software, A.P. and M.P.; Validation, E.D.F., V.P. and C.D.; Formal Analysis, A.P. and M.P.; Investigation, A.P.; Resources, A.P.; Data Curation, A.P. and C.D.; Writing-Original Draft Preparation, M.P.; Writing-Review \& Editing, A.M.P. and E.D.F.; Visualization, M.P., A.P., V.P., A.M.P., C.D., E.D.F. and G.C.; Supervision, G.C.; Project Administration, G.C.; Funding Acquisition, G.C. All authors have read and agreed to the published version of the manuscript.

Funding: This research received no external funding.

Acknowledgments: This research was financed by CarbOnFarm project Life+ENV/IT/000719. We are grateful to the agricultural farm "Prima Luce" involved in CarbOnFarm project as Partner.

Conflicts of Interest: The authors declare no conflict of interest.

\section{References and Notes}

1. Dlgs 152/2006 Decreto Legislativo 3 Aprile 2006, n. 152 Norme in Materia Ambientale. Available online: http://www.camera.it/parlam/leggi/deleghe/06152dl.htm (accessed on 10 April 2019).

2. Dlgs 360/99 “Attuazione Delle Direttive 96/24/CE, 96/25/CE, 98/67/CE e 98/87/CE, Nonché Dell'articolo 19 Della Direttiva 95/69/CE, Relative Alla Circolazione di Materie Prime per Mangimi”. Available online: http://www.parlamento.it/parlam/leggi/deleghe/99360dl.htm (accessed on 10 April 2019). 
3. Achinas, S.; Achinas, V.; Euverink, G.J.W. A Technological Overview of Biogas Production from Biowaste. Engineering 2017, 3, 299-307. [CrossRef]

4. UNI EN 13432. Biodegradabilità e Biocompostabilità. La Norma Volontaria UNI EN 13432. 2000. Available online: https://www.consulenza-qualita.com/norma-uni-en-13432_2002/ (accessed on 10 April 2019).

5. Livestock Engineering Unit \& Environmental Practices Unit Technical Services Division Alberta Agriculture, Food and Rural Development. Manure Composting Manual. 2005. Available online: http://www1.agric.gov. ab.ca/\$department/deptdocs.nsf/all/agdex8875 (accessed on 10 April 2019).

6. Brown, S.; Kruger, C.; Subler, S. Greenhouse gas balance for composting operations. J. Environ. Qual. 2008, 37, 1396-1410. [CrossRef] [PubMed]

7. Quirós, R.; Villalba, G.; Muñoz, P.; Colón, J.; Font, X.; Gabarrell, X. Environmental assessment of two home composts with high and low gaseous emissions of the composting process. Resour. Conserv. Recycl. 2014, 90, 9-20. [CrossRef]

8. Council Directive 1999/31/EC on the Landfill of Waste. Available online: http://ec.europa.eu/environment/ waste/landfill_index.htm (accessed on 10 April 2019).

9. Saer, A.; Lansing, S.; Davitt, N.H.; Graves, R.E. Life cycle assessment of a food waste composting system: Environmental impact hotspots. J. Clean. Prod. 2013, 52, 234-244. [CrossRef]

10. Lal, R. Restoring Soil Quality to Mitigate Soil Degradation. Sustainability 2015, 7, 5875-5895. [CrossRef]

11. Hermann, D.; Sauthoff, S.; Mußhoff, O. Ex-ante evaluation of policy measures to enhance carbon sequestration in agricultural soils. Ecol. Econ. 2017, 140, 241-250. [CrossRef]

12. Bruce, J.P.; Frome, M.; Haites, E.; Janzen, H.; Lal, R.; Paustian, K. Carbon sequestration. J. Soil Water Conserv. 1999, 54, 382-389.

13. Post, W.M.; Kwon, K.C. Soil carbon sequestration and land-use change: Processes and potential. Glob. Chang. Biol. 2000, 6, 317-327. [CrossRef]

14. Ozores-Hampton, M. Compost as an alternative weed control method. Hort. Sci. 1998, 33, 938-940. [CrossRef]

15. Crnko, G.S.; Stall, W.M.; White, J.M. Sweet corn weed control evaluations on mineral and organic soils. Proc. Florida State Hort. Soc. 1992, 105, 326-330.

16. Pane, C.; Palese, A.M.; Spaccini, R.; Piccolo, A.; Celano, G.; Zaccardelli, M. Enhancing sustainability of a processing tomato cultivation system by using bioactive compost teas. Sci. Hort. 2016, 202, 117-124. [CrossRef]

17. Agassi, M.; Shainberg, I.; Morin, J. Slope, aspect and phosphogypsum effects on runoff and erosion. Soil Sci. Soc. Am. J. 1990, 54, 1102-1106. [CrossRef]

18. Albaladejo, J.; Castillo, V.; Diaz, E. Soil loss and runoff on semiarid land as amended with urban solid refuse. Land Degrad. Dev. 2000, 11, 363-373. [CrossRef]

19. Bresson, L.M.; Koch, C.; Le Bissonnais, Y.; Barriuso, E.; Lecomte, V. Soil surface structure stabilization by municipal waste compost application. Soil Sci. Soc. Am. J. 2001, 65, 1804-1811. [CrossRef]

20. Movahedi Naeini, S.A.R.; Cook, H.F. Influence of municipal compost on temperature, water, nutrient status and the yield of maize in a temperate soil. Soil Use. Manag. 2000, 16, 215-221. [CrossRef]

21. Shiralipour, A.; McConnel, D.B.; Smith, W.H. Physical and chemical properties of soils as affected by municipal solid waste compost application. Biomass Bioenerg. 1992, 3, 261-266. [CrossRef]

22. Stocking, M.; Albaladejo, J. Refuse isn't rubbish! Ambio 1994, 23, 229-232.

23. Diacono, M.; Montemurro, F. Long-term effects of organic amendments on soil fertility: A review. Agron. Sustain. Dev. 2010, 30, 401-422. [CrossRef]

24. Recycled Organics Unit (ROU). Life Cycle Inventory and Life Cycle Assessment for Windrow Composting Systems. The University of New South Wales, 2006. Available online: http://www.environment.nsw.gov.au/ resources/warr/2006400_org_slcassesswindrowsys.pdf (accessed on 10 April 2019).

25. Mays, D.A.; Terman, G.L.; Duggan, J.C. Municipal compost: Effects on crop yields and soil properties. J. Environ. Qual. 1973, 2, 89-92. [CrossRef]

26. Persiani, A.; Diacono, M.; Monteforte, A.; Montemurro, F. Agronomic performance, energy analysis and carbon balance comparing different fertilization strategies in horticulture under Mediterranean conditions. Env. Sci. Pollut. Res. 2019, 26, 19250-19260. [CrossRef]

27. Favoino, E.; Hogg, D. The potential role of compost in reducing greenhouse gases. Waste Manag. Res. 2008, 26, 61-69. [CrossRef] [PubMed] 
28. Martínez-Blanco, J.; Muñoz, P.; Anton, A.; Rieradevall, J. Life cycle assessment of the use of compost from municipal organic waste for fertilization of tomato crops. Resour. Conserv. Recycl. 2009, 53, 340-351. [CrossRef]

29. Amlinger, F.; Peyr, S.; Cuhls, C. Greenhouse gas emissions from composting and mechanical biological treatment. Waste Manag. Res. 2008, 26, 47-60. [CrossRef] [PubMed]

30. Boldrin, A.; Andersen, J.; Møller, J.; Christensen, T. Composting and compost utilization: Accounting of greenhouse gases and global warming contributions. Waste Manag. Res. 2009, 27, 800-812. [CrossRef] [PubMed]

31. Edwards, D.; Williams, C. Method for Estimating Greenhouse Gas Emission Reductions from Compost from Commercial Organic Waste. Available online: http://www.arb.ca.gov/cc/protocols/localgov/pubs/compost_ method.pdf (accessed on 1 March 2015).

32. Pergola, M.; Piccolo, A.; Palese, A.M.; Ingrao, C.; Di Meo, V.; Celano, G. A combined assessment of the energy, economic and environmental issues associated with on-farm manure composting processes: Two case studies in South of Italy. J. Clean. Prod. 2018, 172, 3969-3981. [CrossRef]

33. Hamelin, L.; Wesnæs, M.; Wenzel, H.; Petersen, B.M. Environmental consequences of future biogas technologies based on separated slurry. Environ. Sci. Technol. 2011, 45, 5869-5877. [CrossRef] [PubMed]

34. Lopez-Ridaura, S.; van der Werf, H.; Paillat, J.M.; Le Bris, B. Environmental evaluation of transfer and treatment of excess pig slurry by life cycle assessment. J. Environ. Manag. 2009, 90, 1296-1304. [CrossRef]

35. Dalemo, M.; Sonesson, U.; Bjorklund, A.; Mingarini, K.; Frostell, B.; Jonsson, H. ORWARE a simulation model for organic waste handling systems 1: Model description. Resour. Conserv. Recycl. 1997, 21, 17-37. [CrossRef]

36. Diaz, R.; Warith, M. Life-cycle assessment of municipal solid wastes: Development of the WASTED model. Waste Manag. 2006, 26, 886-901. [CrossRef]

37. Diggelman, C.; Ham, R.K. Household food waste to wastewater or to solid waste? That is the question. Waste Manag. Res. 2003, 21, 501-514. [CrossRef]

38. Güereca, L.P.; Gassó, S.; Baldasano, J.M.; Jiménez-Guerrero, P. Life cycle assessment of two biowaste management systems for Barcelona, Spain. Resour. Conserv. Recycl. 2006, 49, 32-48. [CrossRef]

39. Sharma, G.; Campbell, A. Life Cycle Inventory and Life Cycle Assessment for Windrow Composting Systems; Department of Environment and Conservation, University of New South Wales, Recycled Organics Unit: Sydney, Australia, 2003.

40. Sonesson, U.; Björklund, A.; Carlsson, M.; Dalemo, M. Environmental and economic analysis of management systems for biodegradable waste. Resour. Conserv. Recycl. 2000, 28, 29-53. [CrossRef]

41. Bernstad, A.; la Cour Jansen, J. Review of comparative LCAs of food waste management systems e current status and potential improvements. Waste Manag. 2012, 32, 2439-2455. [CrossRef] [PubMed]

42. Martínez-Blanco, J.; Colón, J.; Gabarrell, X.; Font, X.; Sánchez, A.; Artola, A.; Rieradevall, J. The use of life cycle assessment for the comparison of biowaste composting at home and full scale. Waste Manag. 2010, 30, 983-994. [CrossRef] [PubMed]

43. Colón, J.; Martínez-Blanco, J.; Gabarrell, X.; Artola, A.; Sánchez, A.; Rieradevall, J.; Font, X. Environmental assessment of home composting. Resour. Conserv. Recycl. 2010, 54, 893-904. [CrossRef]

44. Bowers, W. Agricultural Field Equipment. In Energy in World Agriculture 6. Energy in Farm Production; Fluck, R.C., Ed.; Elsevier: Amsterdam, The Netherland, 1992; pp. 117-130.

45. Pimentel, D. Energy inputs in production agriculture. In Energy in World Agriculture 6. Energy in Farm Production; Fluck, R.C., Ed.; Elsevier: Amsterdam, The Netherland, 1992; pp. 13-23.

46. Pimentel, D.; Hepperly, P.; Hanson, J.; Douds, D.; Seidel, R. Environmental energetic, and economic comparisons of organic and conventional farming systems. Bioscience 2005, 55, 573-582. [CrossRef]

47. Reganold, J.P.; Glover, J.D.; Andrews, P.K.; Hinman, H.R. Sustainability of three apple production systems. Nature 2001, 410, 926-993. [CrossRef]

48. International Standards Organisation. ISO 14044. Environmental Management Life Cycle Assessment, Requirements and Guidelines; ISO: Geneva, Switzerland, 2006.

49. International Standards Organisation. ISO 14040. Environmental Management Life Cycle Assessment, Principles and Framework; ISO: Geneva, Switzerland, 2006.

50. Ecoinvent Version 3. 2013. Available online: http://www.ecoinvent.org/database/database.html (accessed on 10 April 2019). 
51. Beck-Friis, B.; Smars, S.; Jönsson, H.; Eklind, Y.; Kirchmann, H. Composting of source-separated household organics at different oxygen levels: Gaining an understanding of the emission dynamics. Compost Sci. Util. 2003, 11, 41-50. [CrossRef]

52. Pagans, E.; Font, X.; Sánchez, A. Emission of volatile organic compounds from com-posting of different solid wastes: Abatement by biofiltration. J. Hazard. Mater. 2006, 131, 179-186. [CrossRef]

53. Intergovernmental Panel on Climate Change (IPCC). IPCC Guidelines for National Greenhouse Gas Inventories; 2006 Retrieved 05 01; 2012; Available online: http://www.ipccnggip.iges.or.jp/public/2006gl/index.html (accessed on 2 April 2019).

54. Bjarnadóttir, H.; Friðriksson, G.; Johnsen, T.; Sletsen, H. Guidelines for the Use of LCA in the Waste Management Sector; Nord Test: Espoo, Finland, 2002.

55. Chen, T.; Lin, C. Greenhouse gases emissions from waste management practices using Life Cycle Inventory model. J. Hazard. Mater. 2007, 155, 23-31. [CrossRef]

56. Zhao, W.; Van der Voet, E.; Zhang, Y.; Huppes, G. Life cycle assessment of municipal solid waste management with regard to greenhouse gas emissions: Case study of Tianjin, China. Sci. Total Environ. 2009, 407, 1517-1526. [CrossRef] [PubMed]

57. Hellmann, B.; Zelles, L.; Palojärvi, A.; Bai, Q. Emission of Climate-Relevant Trace Gases and Succession of Microbial Communities during Open-Windrow Composting. Appl. Environ. Microb. 1997, 63, 1011-1018. [CrossRef]

58. Benner, J.H.B.; Otten, M.B.J.; Wielders, L.M.L.; Vroonhof, J.T.W. $\mathrm{CO}_{2}$-kentallen Afvalscheiding. CE, Delft. 2007. Available online: https://www.yumpu.com/nl/document/read/19899334/rapport-co2-kentallenafvalscheiding-tcm24-255007pdf (accessed on 30 October 2019).

59. Heres, R.J.; Tauw, B.V. Research Determining Indicator for Methane and Laughing Gas Composting Plants (Onderzoek Bepalen Kentallen Methaan En Lachgas Composteerbedrijven); WUR: Deventer, The Netherlands, 2007. (In Dutch)

60. PRé Consultants. SimaPro Software Versión 8.04. LCA; PRé Consultants: Dordrecht, The Netherlands, 2015.

61. Guinée, J.B.; Gorrée, M.; Heijungs, R.; Huppes, G.; Kleijn, R.; De Koning, A.; Van Oers, L.; Sleeswijk, A.W.; Suh, S.; De Haes, H.A.U.; et al. Handbook on Life Cycle Assessment, Operational Guide to ISO Standards; Guinée, J.B., Ed.; Kluwer Academic Publishers: Dordrecht, The Netherlands, 2002.

62. Cadena, E.; Colón, J.; Artola, A.; Sánchez, A.; Font, X. Environmental impact of two aerobic composting technologies using life cycle assessment. Int. J. Life Cycle Assess. 2009, 14, 401-410. [CrossRef]

63. Banar, M.; Cokaygil, Z.; Ozkan, A. Life cycle assessment of solid waste management options for Eskisehir, Turkey. Waste Manag. 2009, 29, 54-62. [CrossRef] [PubMed]

64. Blengini, G.A. Using LCA to evaluate impacts and resources conservation potential of composting: A case study of the Asti District in Italy. Resour. Conserv. Recycl. 2008, 52, 1373-1381. [CrossRef]

65. Emery, A.; Davies, A.; Griffiths, A.; Williams, K. Environmental and economic modelling: A case study of municipal solid waste management in Wales. Resour. Conserv. Recycl. 2007, 49, 244-263. [CrossRef]

66. Eriksson, O.; Reich, M.; Frostell, B.; Björklund, A.; Assefa, G.; Sundquvist, J.; Granath, J.; Baky, A.; Thyselius, L. Municipal solid waste management from a systems perspective. J. Clean. Prod. 2005, 13, 241-252. [CrossRef]

67. Singh, V.; Dincer, I.; Marc, A.; Rosen, M.A. Chapter 4. 2 - Life Cycle Assessment of Ammonia Production Methods. In Exergetic, Energetic and Environmental Dimensions; Dincer, C., Colpan, O., Kizilkan, O., Eds.; Elsevier: Amsterdam, The Netherland, 2018; pp. 935-959.

68. Namdari, M.; Kangarshahi, A.A.; Amiri, N.A. Input-output energy analysis of citrus production in Mazandaran province of Iran. Afr. J. Agric. Res. 2011, 6, 2558-2564.

69. Van Haaren, R.; Themelis, N.J.; Barlaz, M. LCA comparison of windrow composting of yard wastes with use as alternative daily cover (ADC). Waste Manag. 2010, 30, 2649-2656. [CrossRef]

70. Diacono, M.; Persiani, A.; Testani, E.; Montemurro, F.; Ciaccia, C. Recycling Agricultural Wastes and By-products in Organic Farming: Biofertilizer Production, Yield Performance and Carbon Footprint Analysis. Sustainability 2019, 11, 3824. [CrossRef]

71. Kolb, W. Effect of soil disinfection and of mulching on the maintenance of plant areas. Gartenemt 1983, 32, 374-376.

(C) 2020 by the authors. Licensee MDPI, Basel, Switzerland. This article is an open access article distributed under the terms and conditions of the Creative Commons Attribution (CC BY) license (http://creativecommons.org/licenses/by/4.0/). 